\title{
Evidence For The Relationship Between Financial Development, Financial Stability and Foreign Direct Investments ${ }^{1}$
}

\author{
Gökhan KARHAN iD a Vehbi AKBULUT iD b \\ a Batman University, Economy Department, Batman, Turkey. gokhankarhan@gmail.com \\ b Batman University, Graduate Student of Economics Department,cBatman, Turkey. vehbiakbulut81@gmail.com
}

\begin{tabular}{|c|c|}
\hline ARTICLE INFO & ABSTRACT \\
\hline $\begin{array}{l}\text { Keywords: } \\
\text { Foreign Direct Investments }\end{array}$ & $\begin{array}{l}\text { Purpose - In this study, the effect of the financial development and financial stability variables } \\
\text { on foreign direct investment were investigated for Turkey. }\end{array}$ \\
\hline $\begin{array}{l}\text { Financial Development } \\
\text { Financial Stability } \\
\text { Economic Growth }\end{array}$ & $\begin{array}{l}\text { Design/methodology/approach - The stationary of the series will be investigated by the ADF } \\
\text { unit root test which developed by Dickey and Fuller (1981). And then, series will be examined } \\
\text { with Rolling Windows Causality and Parameter Estimation Methods which developed by } \\
\text { Balcilar et al. (2010). }\end{array}$ \\
\hline $\begin{array}{l}\text { Received } 30 \text { October } 2018 \\
\text { Revised } 20 \text { January } 2019\end{array}$ & $\begin{array}{l}\text { Findings - Empirical findings suggests that financial stability has a positive effect on the foreign } \\
\text { direct investments especially after 2013; coefficient increased over } 1 \text { for foreign direct } \\
\text { investments in some of the periods. }\end{array}$ \\
\hline Accepted 30 January 2019 & $\begin{array}{l}\text { Discussion - It can be understood from here that a } 1 \% \text { increase in financial stability can affect } \\
\text { foreign direct investments by more than } 1 \% \text {. On the other hand, the causality relationship } \\
\text { between financial development and direct foreign investments is meaningful only for the 2009- } \\
2010 \text { periods. }\end{array}$ \\
\hline
\end{tabular}

Research Article

\section{Introduction}

Capital, which is input of production, is one of the most important inputs used in explaining development differences. Capital shortage and labor abundance are one of the key features of developing countries. Since meeting the required sources for development by savings is impossible in these economies, this deficit is endeavored to be recovered by the foreign capital.

Direct capital investments are the concept to define establishing a new firm in a new region; making an extra investment for the existing foreign company. Direct capital investments can actualize as establishing a new company; opening a branch; building a new facility; buying an existing facility; consolidating with a company; purchasing the company in whole or in part; getting involved in collaborative ventures and making license agreements as well (Çinko, 2009: 118).

United Nations Conferences on Trade and Development (UNCTAD, 2008) defines foreign direct investment (FDI) is a long term relationship between source country (investor companies) and the host country. Accordingly, source company (foreign investor) is described as the company that has an asset in another company or production unit belongs to another country. With reference to this description, it is the situation in which a foreign asset has a right to vote by means of having $10 \%$ or more than $10 \%$ of a company in a country.

Foreign direct investments have a number of effects for both the host country and investor economy. These possible effects are issues that have frequently been discussed in literature. The first studies on this topic go back to 1960s. Rosestein-Rodan's (1961) study that scrutinized the interest of foreign investments for

\footnotetext{
1 This paper was derived from the study entitled "The Effect Of Financial Development And Financial Stability On Foreign Investments", which was accepted as a master thesis in Batman University at January /2019,Institute of Social Sciences. 


\section{G. Karhan - V. Akbulut 11/1 (2019) 227-238}

developing countries is shown as one of the leading studies. It is mentioned in related study that foreign investments that are made in developing countries will increase local capital accumulation in those countries to a level that can be kept without the need of an auxiliary instrument. Moreover, extra products are added to available production capacity by way of the know-how of foreign capital inflow. Thus, there can be reached a higher saving rate in the existing level of income (Nur and Dilber, 2017: 19).

Akdiş (1985) aligns the positive effects of foreign investment on host economies under seven titles. These effects are as follows; national income effect, the balance of payments effects; employment effect, technology effect, the effect of growth, regional development effect, the effect on saving and investments and growth of export, providing foreign currency inflow, closing the current account.

\section{i) Development of Foreign Direct Investments in the Turkish Economy After 1980}

Foreign capital investments in the Turkish economy go back to Ottoman economy. However, the noteworthy period is the period from 1980 to the modern day. Liberal economic policies have been started to be used within the scope of "January 24 decisions" in 1980; this is the noteworthy point.

Turkish economy supported was supported by interventionist government policies till the 1980s; a selfenclosed economic structure based on import-substitution industrialization policy was adopted. Turkish economy opened to foreign countries by January 24 decisions in 1980 and entered into the economic liberalization. Restrictions in interest rates in Turkish economy were removed in 1981; policies of liberalization of exchange followed the process. Under these circumstances, financial markets in Turkey started to need for international capital (Kar and Tatlısöz, 2008: 4).

Turkish economy became open to foreign trade by rallying the relations between the European Union and Turkey in the 1990s and Turkey's membership to Customs Unions in 1996. Foreign capital investment expectation in Turkish economy started by formalizing the EU candidacy at the end of 2003 (Karagöz, 2007: 934).

A series of decisions were taken within the frame of January 24 decisions to incentivize the foreign investor. Related decisions are as follows;

- It was aimed to ease foreign capital inflow in the agriculture and mining sectors and other specific service sectors by means of extending the scope of foreign capital.

- It was enabled to be turned unsecured loans exceeding the US $\$ 500$ million into foreign capital investments.

- It was endeavored to ensure the environment of trust for foreign investors to liberalize the capital inflows and outflows.

- It was enabled to be excluded foreign investments from some restrictions for domestic investors by establishing free zones.

Some specific amendments for the benefit of foreign investors were conducted in related legislation;

- There was brought flexibility to exchange regime.

- Import and export were liberalized.

- Free zones were operationalized.

Turkish economy was made attractive by all these changes. Privatization activities including foreign investments via the build-operate-transfer model in 1980s can be evaluated within this scope (YASED, 1983: $105-106)$.

Short term foreign capital movements entered into the process of liberalization after the 1980s. Restrictions of foreign capital movements were canceled by the Law introduced in 1989. 32 numbered legal decision of Protection of the Value of Turkish Currency Law removed restrictions on foreign capital and allowed foreigners to make a purchase from capital markets in Turkey (Yorulmaz, 2006: 25).

As is mentioned above, privatization has been a significant factor in foreign capital inflow. Privatization activities of public institutions were expedited in the related period. While the public institutions in which 


\section{G. Karhan - V. Akbulut 11/1 (2019) 227-238}

monopoly goods and services are produced were privatizing, foreigners gained an advantage by means of directly addressing a market has a wide consumer group. Indeed, the number of foreign-invested companies within the top 500 was increased 66 to 114 from the 1980s to 1990s.

Laws on free zones came into force in 1985. Related laws for developing the capital markets were enacted in 1981. Tourism promotion frame decision and the law for the encouragement of tourism respectively came into force in 1980 and 1982. There was also a paragraph in regard to being taken precautions for introducing foreign capital policy abroad as from 1988 (Yorulmaz, 2006: 26).

It is seen when the sectoral distribution of foreign capital investments in Turkey after 1980s that there was a flow from developed countries to developing countries. Basic characteristics of this flow are as follows (YASED, 1983: 110).

- Foreign capital investments actualize in sectors that necessitate advanced technology and qualified manpower.

- Foreign capital investments focus on sectors which continuously return a profit in the long term. Improving the sectors like automotive, transportation or mining and also extending subsidiary industries contribute to economic growth.

Foreign capital has an influence on economic mobility within country. Related mobilities are as follows (Yorulmaz, 2006: 110);

1. Chronic inflation problem that became permanent in the 1980s encouraged new foreign capital inflow to the country by increasing the profit margins of foreign investors.

2. Liberal policies in the economy and a free market economy that was tried to have occurred started a process by increasing imported goods. Investments (import substitution) have been preferred for being produced these goods whose demand has increased in time.

3. Long-term and low-interest loan and incentives for foreign capital investors provided the opportunity for great increases in capital in the country.

Effects of foreign capital inflows that started in the 1980s on the national economy can be summarized as follow s;

1. Entering new technologies in Turkey by investments of foreign investors (computer, electronic, electric, automotive). Getting into partnerships between domestic and foreign investors,

2. Significant increases in foreign exchange holdings by foreign investments and being paid taxed by foreign companies in Turkey. These related increases are efficient on development of the economy,

3. Foreign-invested institutions that need for qualified manpower have a role in fulfilling features of labor in Turkey and building capacities.

4. Foreign investors who want to complete infrastructures (electricity, road, water, etc.) in host countries (or regions) help Turkey to speed up the process in this sense.

Besides the positive effects above, foreign capital made huge contributions to issues such as industry and services sector and other issues like total equity and economic issues (gross value added, export, number of employees, balance sheets, profit, etc.) (Yorulmaz, 2006: $44-45)$.

\section{Literature Review}

A literature review about the situation of financial markets and foreign capital inflow is significant to develop the model that was offered in research. Indeed, there are several studies on determinants of foreign capital entered in financial markets. In addition to this, available studies mostly focused on macroeconomic factors. Limited availability of studies worked on risk factors by making the risk analysis of country. In this scope, financial stability can be measured as a risk factor. Otherwise, financial factors that are effective on foreign capital is a subject that was rarely discussed in the literature.

One of the studies about determinants of foreign capital investments belongs to Dunning (1981). The author revealed the importance of foreign direct investment (FDI) inflow to the country by the size of the market, 
unit labor cost and service sector productivity and inflation on FDI. Root and Ahmed (1979) is accepted as another leading study. They analyzed the effects of social status on FDI inflow to the country. Development of human capital, life quality, health system, and urbanization rate are effective factors on FDI inflow. Niels Hermes and Robert Lensink (2003) examined linkages between financial development and foreign direct investments which brings with technological process. Analysis show that development of the financial system is an important precondition for the FDI to have a positive impact on the economic growth. Bevan and Estrin (2004) reviewed the determinants of FDI in multiplex country groups by panel data analysis method. With reference to the research findings of authors who used European countries, the size of the market is effective while the country risk is insignificant on the issue. It was pointed out that efficiency is a remarkable factor in FDI inflow. Janicki and Wunnava (2004) reviewed European countries and member countries. They also inserted unit labor cost, market size and trade openness index in the analysis. According to this research findings, all these factors are important for FDI to enter in countries Nunnekamp (2002) scrutinized the determinants of FDI in terms of developing countries. He also analyzed whether there is a change in factors affecting FDI by the globalization. It was emphasized at the end of the research that significance of production costs and trade openness do not change by globalization; production costs and trade openness are determinants at the same time. FDI inflows increased toward nontradables. Onyeiwu and Shrestha (2004) conducted a study on African countries and reviewed the key determinants of FDI in related countries. With reference to their results, inflation, economic growth, international reserves, economical span and accessibility to natural resources are aligned among important factors rather than political stability and infrastructure competence.

Zukarnain Zakaria (2007) researched causal relationship between FDI and financial development for 37 developing countries. Causality analysis suggests that foreign direct investments have no affect on the development of financial system. Korgaonkar (2012) examined if a well-functioning financial system has an impact on the FDI inflows and outflows of a country using data for 78 countries for the period of 1980-2009. Findings suggests that FDI is not directed into countries that are financially weak. On the other hand FDI is dependent on both the stock market variables and the banking sector variables for selected countries.

Academic studies also performed single country analyses at the same time. Ang (2008), Yol and Teng (2009) and Xose and Palas (2008) can be shown as examples among related studies. Ang (2008) scrutinized Malaysia Economy. Ang who reviewed financial development as a variable resulted that trade openness and infrastructure factors including financial development affect FDI. Adeniyi and Omisakin (2012) investigated between financial development and foreign direct investments for Economic Community of West African States (ECOWAS) from 1970 to 2005 period. According to authors due to the heterogeneity of the economic structure of countries, different components should be used in spesific countries. Ezeoha and Cattaneo (2012) investigated impact of financial development, institutional quality and natural resource endowment on both the stock and the flow of inward foreign direct investment (FDI) to the 38 Sub-Saharan African (SSA) countries with GMM model. Findings shows that in the resource-rich countries, the formal financial system provides an alternative platform for the management of existing FDI stocks and the provision of financial allocation. Bal and Akça (2016) analyzed the determinants of FDI in selected East Asian and Pacific countries. For this purpose, market size, trade openness, macroeconomic stability, infrastructure, and political instability variables were inserted in the model. It was concluded at the end of the research that FDI is affected by trade openness and market size variables Nur and Dilber (2017) considered twelve factors in their research about developing countries; panel data econometric method was used in related research. According to their findings; FDI is affected by corruption, openness, technology, employment and rule of law index.

There also are studies that review the Turkish economy. Those studies analyzed Turkish economy in either single or country group. Erdal and Tatoğlu (2002) are one of those studies mentioned. Authors mentioned that investments affect market size, openness and infrastructure factors.

Berköz and Türk (2007) is the other research that analyzed the Turkish economy. With reference to research results, GDP and population growth, increase in infrastructure investments, increase in credits given to related sectors can be shown as a justification of FDI growth. As is seen in this study, financial development has a significant factor in FDI to a certain extent Yilmazer (2010) reviewed the relationship between FDI, foreign trade and economic growth by causality analysis tests for Turkish economy. It was concluded at the 


\section{G. Karhan - V. Akbulut 11/1 (2019) 227-238}

end of the research that export and import is not essential for FDI; however, economic growth is a significant factor for FDI. Ekinci (2011) evaluated the relationship between FDI, economic growth and employment by causality tests. According to the expressions of author, economic growth is a remarkable factor; the change in employment has no effect on FDI.

It is understood when the studies conducted for Turkey are analyzed that economic growth performance is a remarkable factor in attracting FDI. Moreover, the effects of human capital and other factors on FDI cannot be determined in net. While some of the studies concluded that human capital is effective on FDI, other related studies emphasized the effects of variables relating to production costs on FDI. Furthermore, limited availability of studies are not enough to reflect the net effect of financial development variables on FDI; none of the variables about financial stability inserted in models.

\section{Data, Variables And Model}

\section{i) Data}

Series that belong to nominal values of foreign direct investment that is used as capital flow variable was used in this research. Data (dollar-denominated) which belong to these variables were obtained from electronic data distribution system of the Central Bank of the Turkish Republic.

\section{ii) Variables}

In the second stage, it was understood that financial development needs to be inserted in the model to measure the effect of financial development on foreign capital investments. There need to arise to establish an index to measure financial development. It is observed when the literature is reviewed that different variables are utilized to measure financial development. The ratio of broad money supply (M2) to gross domestic product and also the ratio of loans to the private sector to GDP can be seen among those different variables. The ratio of loans to the private sector to GDP was used to measure the financial development by considering the research of İnançlı et al., (2016). However, a remarkable part of financial system in developing countries like Turkey is composed of banks. Credits rank first among the essential services of private and public banks. This is because it is possible to say that the change in amount of loans to private sector is an important development indicator of the financial system. Values of loans to private sector that are used to measure the financial development were obtained from electronic data distribution system of the Central Bank of the Turkish Republic. Moreover, GDP value was received from electronic data distribution system of the Central Bank of the Turkish Republic to measure the ratio of loans to the private sector to the national income; this related ratio was computed by proportioning these data to each other.

There is a need to constitute an index to measure the financial stability. Therefore, the financial stability index that was created by Aktaş (2011) was considered. Author's index benefits from nine subindexes. Solely one of those subindexes was considered in this study when the scope those subindexes and structure of financial system in Turkey. The used subindex is composed of banking capital adequacy, asset quality, liquidity currency risk and profitability ratio. Those data were received from the database of Banking Regulatory and Supervisory Agency.

Data relating to variables start from 2005 when foreign direct investment data were started to be periodically explained; it continues to the third quarter of the year of 2008. Period range in which quarter data are used was specified as 2005Q4-2018Q3.

\section{iii) Model}

Within the scope of the study, the established models are shown below. For the causality of foreign direct investments from financial development;

$$
F D I_{i t}=\alpha_{i t}+\beta_{1} F D_{i t}+\varepsilon_{i t}
$$

For the causality of foreign direct investments from financial stability;

$$
F D I_{i t}=\alpha_{i t}+\beta_{1} F S_{i t}+\varepsilon_{i t}
$$




\section{iv) Methodology}

Exposure of shocks to economic variables over time has led to the inaccuracy of the results obtained from the analyzes conducted to reduce the reliability of the data. Therefore, the stationary of the data exposed to shocks should be ensured. In this context, it will be tested whether the data carries a unit root or not, and if they carry the unit root, they will be stationarized by taking the differences of the series. In this context, the stationary of the series will be investigated by the ADF unit root test which developed by Dickey and Fuller (1981). And then, series will be examined with Rolling Windows Causality and Parameter Estimation Methods whic developed by Balcilar et al. (2010).

\section{ADF Unit Root Tests}

In time series analysis, the concept of stationary is very important. If the average of a time series and its variance do not change over time, and the covariance between the two periods is depends only distance between the two periods, series is called stationary (Gujarati, 1999). When working with non-stationary time series a spurious regression problem can arises. The ADF model is expressed as follows.

$$
\Delta Y_{t}=\mu+\Phi Y_{t-1}+\sum_{j=1}^{p} \alpha_{j} \Delta Y_{t-j}+\varepsilon_{t}
$$

When the deterministic trend is added to the model

$$
\Delta Y_{t}=\mu+\Phi Y_{t-1}+\sum_{j=1}^{p} \alpha_{j} \Delta Y_{t-j}+\beta_{t}+\varepsilon_{t}
$$

And all test procedures are applied in the same way (Torun, 2015).

\section{Balcılar et. al. (2010) Rolling Window Causality and Parameter Estimation Methods which based on} Bootstrap Method

The causality and parameter estimation method developed by Balcilar provides the causality and parameter for each period used in empirical analysis. Balcilar et al. (2010) apply the probability ratio (LR, likelihood ratio) criterion to the error term with bootstrap method. For the two variables, vector autoregression model with optimal lag length, $t=1,2, \ldots . . \mathrm{T}$;

$y_{t}=\Phi_{0}+\Phi_{1} y_{t-1}+\ldots+\Phi_{p} y_{t-p}+\varepsilon_{t}$

$\varepsilon_{t}=\left(\varepsilon_{1}, \varepsilon_{2}\right) \square i i d\left(0, \sigma^{2}\right)$ The error term indicates white noise. The optimal lag length is calculated by

Akaike Criterion. Where $y_{t}=\left[y_{1 t}, y_{2 t}\right]_{2 x 1}$ is an independent matrix of variables. VAR (p);

$\left[\begin{array}{l}y_{1 t} \\ y_{2 t}\end{array}\right]=\left[\begin{array}{l}\phi_{10} \\ \phi_{20}\end{array}\right]+\left[\begin{array}{ll}\phi_{11}(L) & \phi_{12}(L) \\ \phi_{21}(L) & \phi_{22}(L)\end{array}\right]\left[\begin{array}{l}y_{1 t} \\ y_{2 t}\end{array}\right]+\left[\begin{array}{l}\varepsilon_{1 t} \\ \varepsilon_{2 t}\end{array}\right]$

Here $\phi_{i j}(L)=\sum_{k=1}^{p} \phi_{i j}, k L^{k}, \mathrm{i}, \mathrm{j}=1,2 \mathrm{k}$ is the lag operator. $L^{k} x_{t}=x_{t-k}$. The null hypothesis of the test $\phi_{12, i}=0$, $y_{2 t}$ states that there is no Granger causality between variables. The alternative hypothesis shows that there is causality between variables.

\section{Empirical Findings}

The first thing that should be performed before applying econometric time series with methodological information tests is the unit root tests. Because the behaviors of series affect durableness of analysis results. In fact, regression tests may give misleading results if the series includes unit root. Therefore, unit root tests were first applied in this study. Table 1 shows the results of correlation test that was conducted before unit root tests. 
G. Karhan - V. Akbulut 11/1 (2019) 227-238

Table 1. Correlations Between Variables

\begin{tabular}{lccc}
\hline & FDI & FD & FS \\
FDI & - & & 0.372 \\
FD & -0.166 & - & \\
FS & & -0.524 & - \\
\hline
\end{tabular}

Note: Prepared by author

As is seen in Table 1, there is a positive correlation (0.372) between foreign direct investments and financial stability. A negative correlation (-0.524) can be seen between financial stability and financial development. These results show us there may be a relationship between financial stability and foreign direct investments; also between financial development and portfolio investment.

Table 2. Descriptive Statistics Belong Variables

\begin{tabular}{cccc}
\hline & FDI & FD & FS \\
\hline Average & 7.275049 & 0.357481 & 4.571959 \\
Median & 7.257341 & 0.433425 & 4.552586 \\
Maximum & 8.042699 & 0.857794 & 5.046572 \\
Minimum & 6.576470 & -0.447057 & 4.298163 \\
Standard Deviation & 0.314724 & 0.367760 & 0.188517 \\
Bias & -0.134438 & -0.464147 & 0.811422 \\
Kurtosis & 2.570149 & 1.938488 & 2.995875 \\
Jarque-Bera & 0.556977 & 4.308503 & 5.706222 \\
Probability & 0.756927 & 0.115990 & $0.057665^{*}$ \\
\hline
\end{tabular}

There is no information on descriptive statistics in Table 2. The standard deviation that is the indicator of volatility is seen in financial development at maximum and financial development at a minimum. The criterion in the coefficient of skewness that shows the asymmetry in probability distribution is zero. If it is bigger than zero, distribution is right-skewed; if it is smaller than zero, distribution is left-skewed. Foreign direct investments and financial development are left-skewed; financial stability is right-skewed. Criterion is three in coefficient of kurtosis. If it is smaller than three, distribution is oblate; if it is bigger than three, distribution is orthogonal. As is seen in results in Table, all the variables are oblate. Variable shows a normal distribution based on the null hypothesis in Jarque-Bera normal distribution test. However, the variable does not show a normal distribution based on the alternative hypothesis. Under this circumstance, the alternative hypothesis that shows there is not a normal distribution for financial stability variable at $10 \%$ significance level is accepted. A null hypothesis which accepts the presence of normal distribution in foreign direct investments and financial development variables is accepted.

Unit root test is required after correlation and descriptive statistics toward variables are given. Unit root tests that were developed by Dickey-Fuller (1981, ADF) were used in this chapter. 
G. Karhan - V. Akbulut 11/1 (2019) 227-238

Table 3. ADF (1981) Unit Root Test Results

\begin{tabular}{|c|c|c|c|c|c|}
\hline \multirow{7}{*}{ Level } & & Variables & $\mathrm{ADF}$ & & $\mathrm{ADF}$ \\
\hline & \multirow{3}{*}{ Constant } & FDI & $\begin{array}{l}-4.159(0) \\
{[0.00]^{* * *}}\end{array}$ & & $\begin{array}{c}-10.748(0) \\
{[0.00]^{* * *}}\end{array}$ \\
\hline & & FD & $\begin{array}{l}-3.013(6) \\
{[0.041]^{* *}}\end{array}$ & & $\begin{array}{c}-7.761(5) \\
{[0.00]^{* * *}}\end{array}$ \\
\hline & & FS & $\begin{array}{c}-2.275(1) \\
{[0.183]}\end{array}$ & & $\begin{array}{c}-7.856(1) \\
{[0.00]^{* * *}}\end{array}$ \\
\hline & \multirow{3}{*}{$\begin{array}{l}\text { Constant }+T \\
\text { rend }\end{array}$} & FDI & $\begin{array}{c}-4.490(0) \\
{[0.00]^{* * *}}\end{array}$ & & $\begin{array}{c}-10.752(0) \\
{[0.00]^{* * *}}\end{array}$ \\
\hline & & FD & $\begin{array}{c}0.988(7) \\
{[0.99]}\end{array}$ & & $\begin{array}{c}-4.135(5) \\
{[0.011]^{* *}}\end{array}$ \\
\hline & & FS & $\begin{array}{l}-5.327(0) \\
{[0.00]^{* * *}}\end{array}$ & & $\begin{array}{c}-7.793(1) \\
{[0.00]^{* * *}}\end{array}$ \\
\hline
\end{tabular}

Note: The figures in parenthesis denote the lag length selected by the Schwarz criterion. ${ }^{* *},{ }^{* *}$, and * denote statistical significance at the $1 \%, 5 \%$ and $10 \%$ level of significance, respectively. Values within the brackets shows the probability ratios. For the ADF test: The results of Dickey Fuller test in the case of zero lag length and lag length chosen due to SIC criteria. For the ADF test, the Mac Kinnon(1996) critical values for with constant $-.3 .485,-2.885$ at the $1 \%$, and $5 \%$ levels. The critical values for with constant and trend $-4.035,-3.447$ at the $1 \%$ and $5 \%$ levels, respectively.

Table 3 shows Dickey-Fuller (1981, ADF) unit root test results. With reference to Dickey-Fuller (1981) test results, foreign direct capital investments do not carry unit root at level value. Thus, it will be assumed that the variables are $\mathrm{I}(0)$ in analyses. It is also observed that financial development variable is at stationary at $5 \%$ significance level and level value in a model with constant; however, the same variable is not stationary at a level value in a model with constant and trend. Financial development is stationary when it is the first difference is computed. Financial stability variable carries unit root at a level value in the model with constant; however, financial stability is stationary at $1 \%$ significance level in a model with constant and trend variable. Financial stability is stationary when its first difference is taken. In conclusion, the analysis is continued by taking account the level value of foreign direct investments, first differences of financial development and financial stability variables.

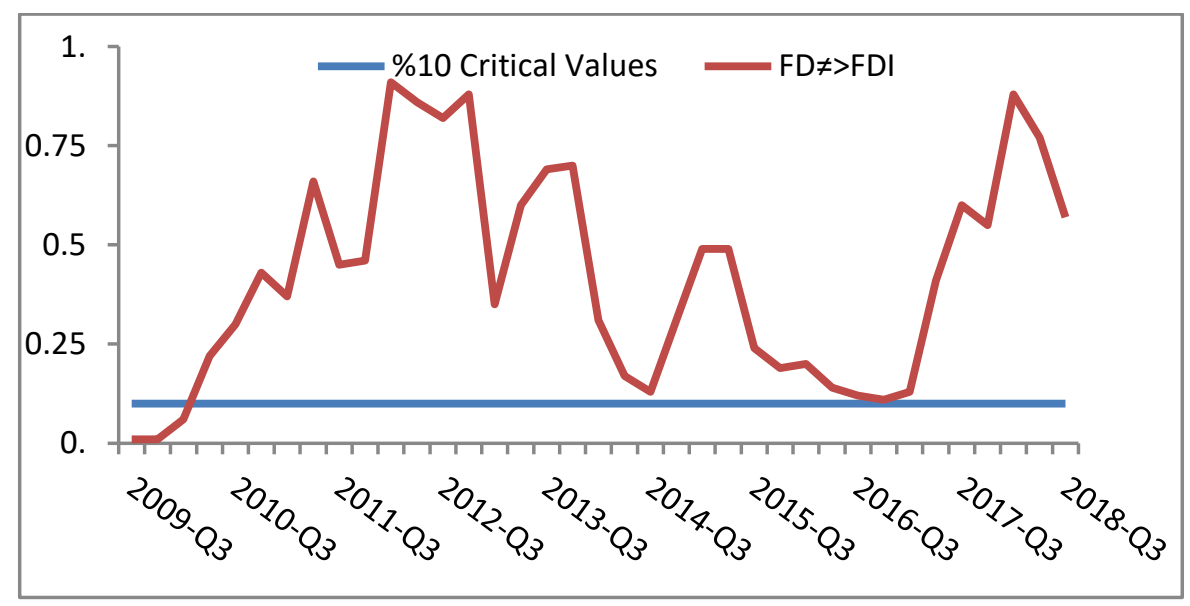

Graphic1. Balc1lar et al., (2010) Rolling Window Causality Test Results from Financial Development to Foreign Direct Investments Note: Prepared by author.

The efficiency of financial development on FDI was tested in Graphic 1. There is causality from financial development to foreign direct investment in the third and fourth quarters of the year of 2009; the first 


\section{G. Karhan - V. Akbulut 11/1 (2019) 227-238}

quarter in the year 2010. Financial development became a significant criterion for FDI after the global crisis; however, its effectiveness took a short time.

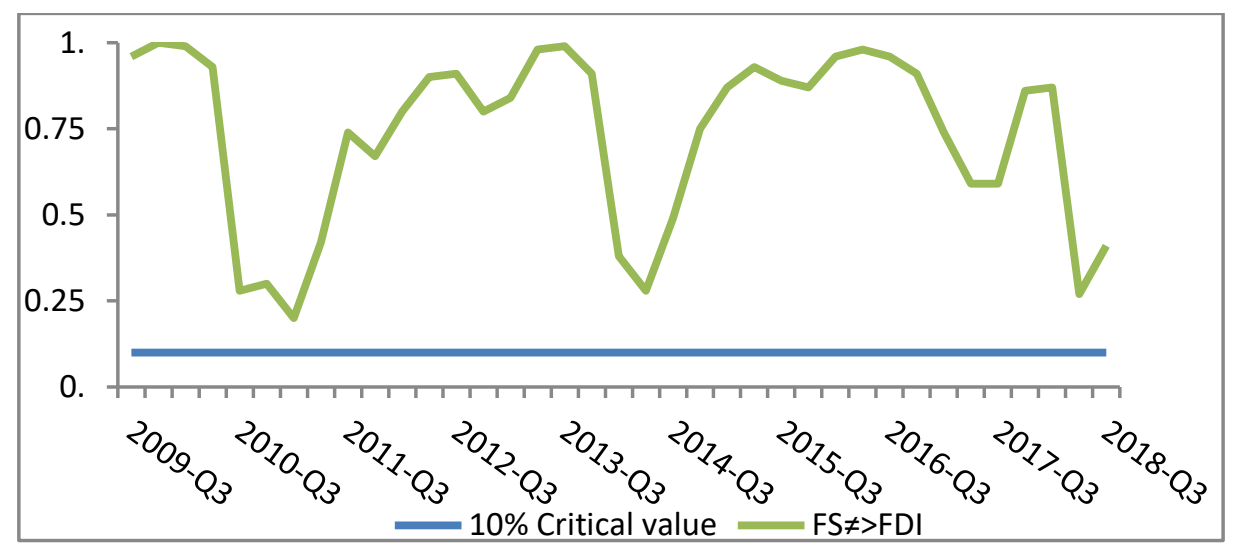

Graphic 2. Balcılar et al., (2010) Rolling Window Causality Test Results from Financial Stability to Foreign Direct Investments Note: Prepared by author.

Graphic 2 shows the effect of financial stability on FDI. According to related findings, there is no causality from financial stability to foreign direct investments in none of the periods. Namely, financial stability does not affect the portfolio investments and FDI at the same time.

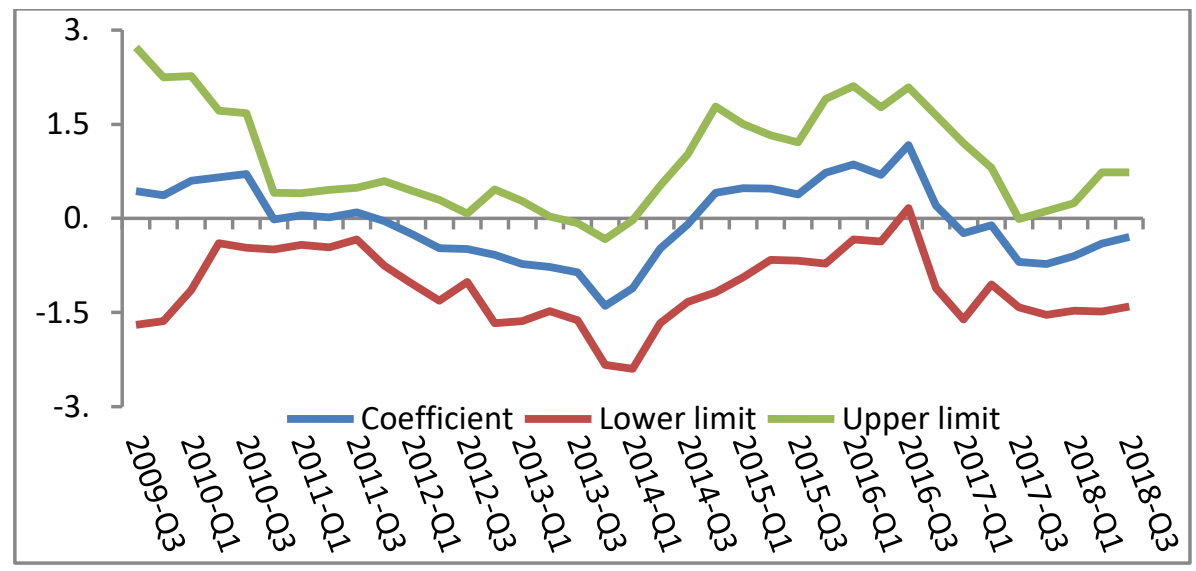

Graphic3. Balcılar et al., (2010) Rolling Window Causality Test Results from Financial Development to Foreign Direct Investments Note: Prepared by author

Graphic 3 and 4 show the results of the analysis that was applied to review to what extent foreign direct investments are affected by financial development and stability. As is seen in Graphic 3, the effect of financial development on foreign direct investments is positive from the third quarter of 2009 to the third quarter of 2011 (except the fourth quarter of 2010). The lowest effect actualized in the second quarter of 2011(0.013); the highest effect actualized in the third quarter of 2010 (0.709).

Effect of financial development on foreign direct investments was negative from the fourth quarter of 2011 to the third quarter of 2014. The lowest effect was in the fourth quarter of 2011 (0.045); the highest effect was in the first quarter of 2014 (1.11042). Effect of the financial development on foreign direct investments was negative from the fourth quarter of 2014 to the fourth quarter of 2016. In the same period, the lowest effect actualized as 0.203 in the fourth quarter of 2016; the highest effect actualized as 1.168 in the third quarter of 2016. Effect of the financial development on foreign direct investments is negative from the first quarter of 2017 to the end of the empirical analysis period. In the same period, the lowest effect actualized as 0.108 in the second quarter of 2017; the highest effect actualized as 0.724 in the fourth quarter of 2017. Accordingly, financial development created a multiplier effect on foreign direct investments in the first quarter of 2014 and the third quarter of 2016. In addition to all these, effect of financial development on FDI cyclically followed a fluctuating course. 


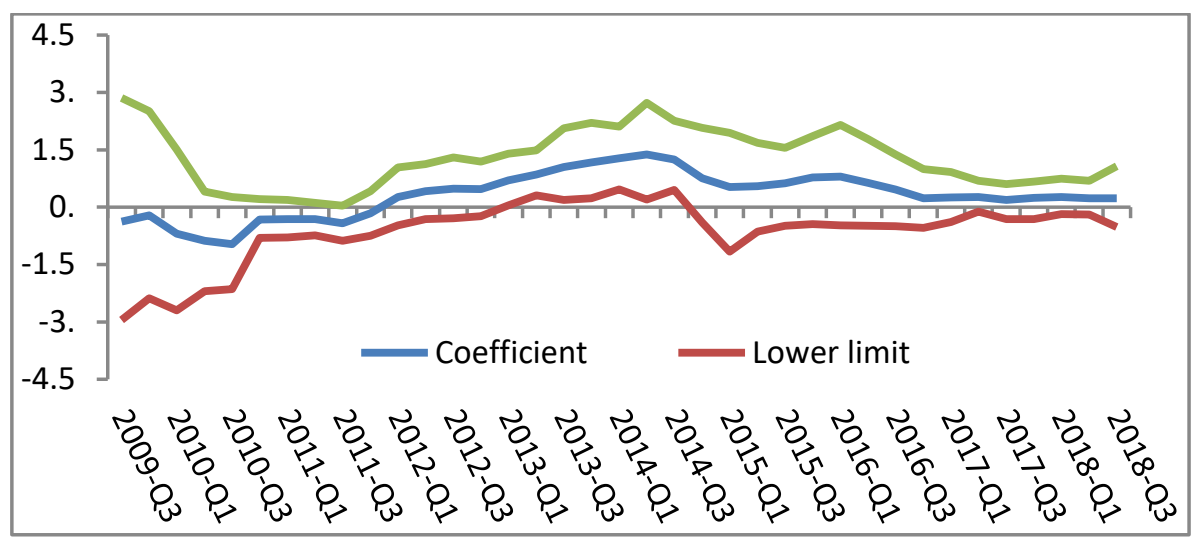

Graphic 4. Balcilar et al., (2010) Rolling Window Regression Test Results from Financial Stability to the Foreign Direct Investments Note: Prepared by author

Graphic 4 shows the course belongs to the coefficient represents the effectiveness of financial stability on FDI. Effect of financial stability on the foreign direct investment was negative from the third quarter of 2009 to the fourth quarter of 2011. In related period, the lowest effect actualized as 0.157 in the fourth quarter of 2011; the highest effect actualized as 0.967 in the third quarter of 2010. Effect of financial stability on foreign direct investments was positive from the first quarter of 2012 to the third quarter of 2018. In the period mentioned, the lowest effect actualized as 0.1907 in the third quarter of 2017; the highest effect actualized as 1.378 in the second quarter of 2014. Namely, financial stability created a multiplier effect on foreign direct investments in the period from the third quarter of 2013 to the third quarter of 2014.

\section{Conclusion}

In this study, an empirical model was established to find to what extent the FDI is affected by financial development and stability. Data that were inserted in the model were defined; finally, we informed on the sources of data. Afterward, econometric methodologies were introduced.

The last part of the chapter gave and commented the results of econometric time analysis; rolling window causality and regression analyses.

Rolling window regression analysis results confirmed that financial development has negative (Korgaonkar, 2012; Fakhreddin et.al., 2011) and positive effects (Zakaria, 2007; Nasser and Gomez, 2009; Dutta and Roy, 2011) on foreign direct investments based on cyclical fluctuations as results of Zadeh and Madani (2012) and Konstantinos et al. (2010). Kar and Tatlısöz (2008) state that the financial stability is of great importance in the presence of much of the foreign capital stock in the developed countries. We also see that financial stability has a positive effect on the foreign direct investments especially after 2013; coefficient increased over 1 for foreign direct investments in some of the periods. It can be understood from here that a $1 \%$ increase in financial stability can affect foreign direct investments by more than $1 \%$.

In conclusion, both financial stability and financial development are effective on the foreign capital inflow. Moreover, it is possible to say that financial stability has become important for this type of foreign capital in the period after 2013. There is an undeniable fact that the effect of financial stability is more effective in comparison with financial development. It is understood via this undeniable fact that either financial development with a total net asset value of fund or instrument variety has remained incapable for financial capital to enter the country from abroad. Regulatory and supervisory authorities need to effort for financial stability as well. 


\section{References}

Adeniyi, O., and Omisakin, O. (2012). Foreign direct investment, economic growth and financial sector development in small open developing economies. Economic Analysis and Policy, 42(1), 105-128.

Akdiş, M. (1985). Dünya'da ve Türkiye'de Yabancı Sermaye Yatırımları ve Beklentiler. YASED Yayınları, 1985.

Aktaş, C. (2011). Finansal İstikrar Analizi Bağlamında Türkiye İçin Finansal İstikrar Endeksi Önerisi. Yayımlanmamış Doktora Tezi, Ankara Üniversitesi Sosyal Bilimler Enstitüsü, Ankara

Albulescu, C. T., Briciu, L., \& Coroiu, S. I. (2010). Determinants of foreign direct investment in CEECs: the role of financial stability. Scientific Annals of the "Alexandru Ioan Cuza". Economic Sciences Section, Special Issue, 85-96.

Ang, J. B. (2008). Determinants of Foreign Direct Investment in Malaysia. Journal of Policy Modeling, 30, ss.185-189.

Bal, H. and Akça, E. (2016). Doğrudan Yabancı Sermaye Yatırımlarının Belirleyicileri: Seçilmiş Doğu Asya ve Pasifik Ülkelerinden Ampirik Bulgular. Sosyoekonomi, 24 (30), 91-112.

Balcılar, M., Özdemir, Z.A. ve Arslantürk, Ö. (2010). Economic Growth and Energy Consumption Causal Nexus a Viewed Through a Bootstrap Rolling Window. Energy Economics, 32, 1398-1410

Berköz, L and Turk, S. S. (2007). Yabancı Yatırımların Yer Seçimini Etkileyen Faktörler: Türkiye Örnegí. itüdergisi Mimarlık, Planlama, Tasarım, 6 (2), ss. 59-72.

Bevan, A. and Estrin, S. (2004). The Determinants of Foreign Direct Investment into European Transition Economies. Journal of Comparative Economics, 32, ss. 775-787.

Ç̧inko, L. (2009). Dogrudan Yabancı Sermaye Hareketlerinin Makroekonomik Etkileri. Marmara Universitesi I.I.B.F. Dergisi, 16(1).

Dickey, D. A. and Fuller, W. A. (1981). Likelihood Ratio Statistics for Autoregressive Time Series with a Unit Root. Econometrica, 49, ss. 1057-1072.

Dunning, J.H. (1981). Explaining the International Direct Investment Position of Countries: Towards a Dynamic or Developmental Approach. Weltwirtschaftliches Archiv, 117, ss. 30-64.

Dutta, N., and Roy, S. (2011). Foreign Direct Investment, Financial Development And Political Risks. The Journal of Developing Areas, 44(2), 303-327. Retrieved from http://www.jstor.org/stable/23215253

Ekinci, A. (2011). Dogrudan Yabancı Yatırımların Ekonomik Büyüme ve Istihdama Etkisi: Tưrkiye Uygulaması 1980-2010. Eskișehir Osmangazi Universitesi IIBF Dergisi, Ekim, 2011, 6(2), ss. 71-96.

Erdal, F. and Tatoğlu, E. (2002). Locational Determinants of Foreign Direct Investment in An Emerging Market Economy: Evıdence From Turkey. Multinational Business Review, 10 (1), ss. 1-7.

Ezeoha, A. E., and Cattaneo, N. (2012). FDI flows to Sub-Saharan Africa: The impact of finance, institutions, and natural resource endowment. Comparative Economic Studies, 54(3), 597-632

Fakhreddin, F., Nezakati, H., and Vaighan, B. M. (2011). The determinants of FDI inflow in manufacturing sector of Malaysia. Journal for International Business and Entrepreneurship Development, 5(4), 299314.

İnançlı, S., Altıntaş, N. and İnal, V. (2016). Finansal Gelişme ve Ekonomik Büyüme İlişkisi: D8 Örneği. Kastamonu Üniversitesi İ̈BF Dergisi, 14, 36 - 49.

Janicki, H. P. and Wunnava, P. V. (2004). Determinants of Foreign Direct Investment:Empirical Evidence from EU Accession Candidates. Applied Economics, 36, ss. 505-509.

Kar, M. and Tatlisöz, F. (2008). Türkiye'de Dogrudan Yabancı Sermaye Hareketlerini Belirleyen Faktörlerin Ekonometrik Analizi. KMU ITBF Dergisi, 10 (14), ss. 1-23. 


\section{G. Karhan - V. Akbulut 11/1 (2019) 227-238}

Karagöz, K. (2007). Türkiye'de Dogrudan Yabancı Yatırım Giriş̧lerini Belirleyen Faktörler: 1970:2005. Journal of Yasar University. 2(8), ss. 927-948.

Konstantinos, S., Alexandros, G., Emmanuel, S. and Chatsivasileladou, S. (2010) Financial development and economic growth: an empirical research from Greece - Cointegration Test. International Conference on Applied Economics.

Korgaonkar, C. (2012). Analysis of the impact of financial development on foreign direct investment: A data mining approach. Journal of Economics and Sustainable Development, 3(6). 70-79.

Nasser, O., and Gomez, X. G. (2009). Do well-functioning financial systems affect the FDI flows to Latin America? International Research Journal of Finance and Economics, 29, 60-75.

Niels Hermes and Robert Lensink (2003), “Foreign Direct Investment, Financial Development and Economic Growth", Journal of Development Studies, Vol.38

Nunnenkamp, P. (2002). Determinants of FDI in Developing Countries: Has Globalization Changed the Rules of the Game. Kiel Working Paper, No.1122, ss.1-44.

Nur, H. B. and Dilber, İ. (2017). Gelişmekte Olan Ülkelerde Doğrudan Yabancı Yatırımları Belirleyen Temel Unsurlar. Dokuz Eylül Üniversitesi İktisadi ve İdari Bilimler Fakültesi Dergisi, 32 (2), ss. 15 - 45.

Nur, H. B. and Dilber, İ. (2017). Gelişmekte Olan Ülkelerde Doğrudan Yabancı Yatırımları Belirleyen Temel Unsurlar. Dokuz Eylül Üniversitesi İktisadi ve İdari Bilimler Fakültesi Dergisi, 32 (2), ss. 15 - 45.

Onyeiwu, S. and Hemanta, S. (2004). Determinants of Foreign Direct Investment in Africa. Journal of Developing Societies, 20 (12), ss. 90-106.

Root, F. and Ahmed, A. (1979). Empirical Determinants of Manufacturing Direct Foreign Investment Developing Countries. Economic Development and Cultural Change. 27, ss. 751-767.

Rosenstein - Rodan, P.N. (1961). International Aid For Underdeveloped Countries. Center For International Studies. Massachusetts Institute of Technology, Cambridge.

Torun, N. (2015). Birim Kök Testlerinin Performanslarının Karşılaştırılması. İstanbul Üniversitesi, Sosyal Bilimler Enstirüsü, Ekonometri Anabilimdalı, Yüsek Lisans Tezi.

United Nations Conference on Trade and Development UNCTAD, (2008): World Investment Report: Transnational Corporations and the Infrastructure Challenge.

Xose, R. and Pallas, J. (2008). Determinants of Foreign Direct Investment in Spain. Applied Economics, Taylor \& Francis Journals, 40(19), ss. 2443-2450.

YASED (1983). Dis, Ulkelerde Yabancı Sermaye Tecrubesi. Seminer 1, Oztürk Matbaası, Istanbul.

Yilmazer, M. (2010). Dogrudan Yabancı Yatırımlar, Dis, Ticaret ve Ekonomik Büyüme Ilişsisi: Türkiye Uzerine Bir Deneme. Celal Bayar Universitesi SBE Dergisi, 8 (1).

Yol M. A. and Teng, N. T. (2009). Estimating the Domestic Determinants of Foreign Direct Investment Flows in Malaysia:Evidence from Cointegration and Error-Correction Model. Jurnal Pengurusan, 28, 2009, ss.3-22.

Zadeh, H.A. and Madani, Y. (2012) Financial market development, fdi and economic growth in Iran. Journal of Basic and Applied Scientific Research 2(1): 228-230.

Zakaria, Z. (2007). The causality relationship between financial development and foreign direct investment. Jurnal Kemanusiaan, 10. 1-23.

Zukarnain Zakaria (2007), "The causality relationship between financial development and foreign direct investment", Jurnal Kemanusiaan bil.10, December 2007 